Vienna institute hit by espionage charges

Claims force Soviet official

\section{to resign}

Allegations of espionage for the Soviet Union have forced the resignation of Dr Arkady Belozerov as secretary of the Institute of Applied Systems Analysis at Laxenburg, near Vienna. This dramatic development has intensified anxiety at the institute about its long-term financial security, already threatened by the Reagan Administration.

Dr Belozerov was appointed to his post at the institute in 1971, and took up his job in December that year. An article in the British news magazine Now! on 10 April said that Dr Belozerov, a plasma physicist by training, was also an agent of the KGB who had been the Soviet contact with a Norwegian double agent during his spell in Vienna. A statement put out by the institute on 15 April said that Dr Belozerov had offered his resignation and that this had been accepted.

The responsibilities of the secretary of the institute are largely those of external relations with member organizations (mostly national academies), potential donors (such as foundations) and the press. As with other senior posts at the institute, the secretary is appointed jointly by the director and the governing council. Dr Belozerov's name was the only nomination before the council in 1979. The institute's policy on recruitment requires that there should be a national balance among senior members of the staff.

The allegation in the Now! article is that Belozerov took over from another Viennabased Soviet agent responsibility for keeping contact with a Norwegian petroleum engineer known as Jansen. According to the magazine, "Jansen"' began working as a double agent for the Norwegian security services six years ago, providing a succession of Soviet contacts in Oslo and then Vienna with innocuous and sometimes misleading information about petroleum operations in the North Sea and the China Sea.

Dr Belozerov is reported to have met "Jansen" on several occasions in Vienna, to have been incompetent in making arrangements for meetings and to have been reluctant to pay for information provided until its authenticity had been checked. He is reported to have given a full account of his career as a member of the $\mathrm{KGB}$ and in the process to have revealed the identity of a Soviet agent in Austria. His meeting with "Jansen" arranged for 4 April outside the Volks Opera in Vienna is said to have been frustrated by the expulsion of another alleged Soviet agent

\section{from Norway}

In his letter of resignation to the institute, Dr Belozerov protests that the allegations "are without factual basis", but that there is no impartial forum in which he can demonstrate them to be false. His letter says that he offered his resignation "in the interests of the institute".

The institute says that Dr Belozerov's conduct of his post as secretary had been "completely satisfactory" but that it has no way of independently determining the truth of the allegations against him and therefore had no choice but to accept his resignation. A spokesman said last week that in the present precarious financial circumstances, any member of the staff against whom allegations of this kind were made would be asked to leave.

One curious feature of the Belozerov affair, as reported, is that Soviet agents should have been willing to pay for information about oil technology in deep waters

\section{Schuster quits as EEC}

\section{Brussels}

The reshuffle of top jobs at the European Commission following the appointment of commissioners and the allocation of their portfolios at the beginning of 1981 has led to a flurry of resignations during the past two weeks, and rumours that some directorates-general are to be reorganized are gathering force.

Five directors-general are known to be leaving, among them Günter Schuster, head of Research, Science and Education (DG XII). His resignation was handed in amid speculation that he is dissatisfied with the way responsibility for DG XII has been split among three commissioners. At the beginning of the year, infighting among the new 14-man Commission caused a messy distribution of the research portfolios. Etienne Davignon (France) grabbed research and science, leaving Ivor Richards (United Kingdom) with education and training, and Karl-Heinz Narjes (West Germany) with industrial innovation.

Some members of the Commission claim that this arrangement is not as awkward as it might seem - decisions taken by the commissioners have in any case to be unanimous. The real reason for Schuster's departure may be that at 62 he would be due for retirement mid-way through the next four-year indirect action programme now being planned. A new man would be able to see the plan to completion.

His departure leaves a vacuum hard to fill. According to a close colleague, Herbert Allgeier, Schuster's greatest personal achievement was to build up from scratch the European Community's research policies from the shambles that followed the collapse of the Euratom programme at the end of the $1960 \mathrm{~s}$. Pressure is now being brought to bear on Davignon to such as those of the North Sea when the institute itself had only recently published an up to date account of the field.

The Austrian government, an enthusiastic benefactor of the institute, has reacted protectively. The Minister of the Interior, Mr I. Lanc, said last week that Belozerov had committed no offence under Austrian law and complained that "certain countries" not having common frontiers with the Soviet Union had come to undervalue detente and to regard the Institute of Applied Systems Analysis as an expendable target.

The institute's financial prospects are not nearly as bright as they may have seemed only a few months ago. Although the member organizations of the institute are national academies, most of these are reimbursed by their governments for the cost of membership. The Soviet Academy of Sciences and the United States National Academy of Sciences are the largest con-

\section{research director}

find a replacement as soon as possible, so that the new appointee can help draw up the new research policy guidelines.

Among the names being mooted is that of Fabrizio Caccia Dominioni, at present looking after research, development and nuclear policy. However,somebody may well be brought in from outside, although probably not another German or Briton. Leonard Williams of the

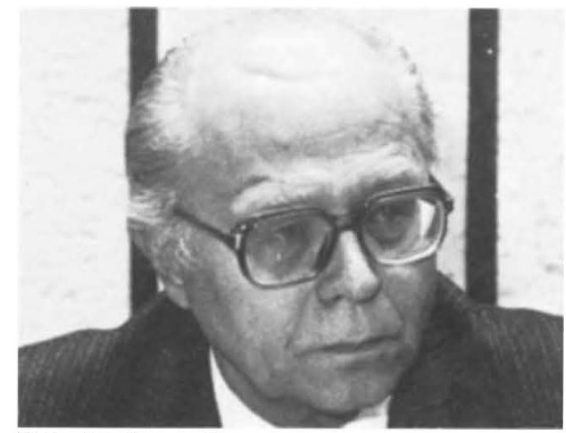

Schuster leaves the scene

energy directorate-general is being replaced by Christopher Audlands. In the best Byzantine traditions, the top jobs are distributed so that national pride and influence are not diminished with each four year reshuffle.

Other changes are rumoured, but one decision, it seems, has definitely been taken. The Environment and Consumer Protection Service (ECPS) is to be elevated to directorate-general status thanks partly to the patronage of the European Parliament. The ghostly DG XI, which was left vacant after an earlier round of administrative musical chairs, will once more have an occupant. Michel Carpentier will remain in charge as head of ECPS and will henceforth be officially addressed as director-general.

Jasper Becker 
tributors at rather more than $£ 1$ million each a year.

In the United States, the National Academy's annual contribution has since the inception of the institute been met by the National Science Foundation from its allocation of funds for international activities, cut in President Reagan's first budget from $\$ 15$ million to $\$ 10$ million for the coming financial year. After protests from the academy that the statutes of the institute require twelve months' notice of withdrawal, the putative contribution for 1982 has now been restored to the foundation's budget, but on the strict understanding that this will be the last contribution to be sanctioned by the Administration.

In principle, tilere is no reason why the academy should not seek to raise its annual contribution from some other source than the United States government, but in present circumstances this will not be easy. The 1982 budget for the institute will be agreed between the member institutions at two council meetings to be held in June and November this year. The United States academy will have to give notice of intended withdrawal at the end of this year if it is not by then assured of funds with which to pay its 1983 subscription.

It is ironical that the institute, founded partly with the intention of providing a place at which people from East and West could work on problems of international importance, should have run into trouble because of allegations of espionage.

\section{US graduate employment}

\section{Industry has jobs}

\section{Washington}

Despite continued uncertainty in the US economy, business is booming for engineering graduates - and natural scientists are not far behind. Figures just released by the College Placement Council of Bethlehem, Pennsylvania, reveal that engineers who expect to graduate this summer are already being offered starting salaries of up to $\$ 26,000$, a 10 per cent increase over last July. Graduates in physical and Earth sciences were being offered $\$ 22,000$, an 18 per cent rise compared with last year.

This rapacious demand for technical graduates has been confirmed by a report from a New York consulting firm, Deutsch, Shea and Evans, which claims that there has been a sharp up-swing in employment prospects for graduate engineers since last November. And the figures are in marked contrast with starting salaries for arts graduates, which average about $\$ 12,000$, with many failing to find any jobs at all.

The shortage of engineers is partly a reflection of declining enrolments in university engineering schools. For example, 2,751 engineering doctoral degrees were awarded in 1980, compared with 3,074 in 1972; although this also reflects the fact that fewer engineers are staying on to do graduate work, the 1980 figures include more than 60 per cent foreign students, many of whom were not expected to stay in the United States.

Recruitment difficulties have also produced near-crisis in the engineering schools, few of which can afford to match salaries in industry. According to William A. Cox, president of the National Society of Professional Engineers, there are now 1,800 unfilled faculty positions in engineering schools - a situation which has led the society to add its voice to those asking Congress for federal assistance to upgrade facilities and research equipment to make the educational environment more attractive.

There is also a feeling that the turnaround in demand for technical graduates reflects greater optimism in the economy than six months ago. "In general, the market in technical areas is the best that it has been for years", says Victor Lindquist, director of the placement office at Northwestern University which carries out regular surveys of employment prospects. He claims, for example, that metal companies such as mining and steel, sectors which are likely to benefit directly from a significant increase in military spending, seem to be stockpiling talent in anticipation of a quick recovery in the economy.

The College Placement Council survey revealed that, as in the past, engineers represent the hottest buy in the employment market. More than 63 per cent of the job offers reported in the survey as having been received by mid-March were to future engineering graduates, although these only made up 7 per cent of the bachelor degree graduates in 1980-81.

In proportional numbers of offers, the scientific disciplines were dominated by computer science graduates, another field where demand is considerably in excess of supply, a point which has been made recently by the National Science Foundation. However, the average starting salary offered to such graduates of $\$ 19,968$ was considerably lower than the $\$ 21,912$ offered to graduates in physical sciences.

Among masters level graduates, the highest offers went to chemical engineering graduates, with an average starting salary of $\$ 26,240$ - almost 13 per cent higher than the figures last July. Geology and related geological sciences, in strong demand in the petrochemical and mining industries, ranked second with an average salary of $\$ 25,380$. All these figures are based on offers reported by placement offices at 161 US colleges and universities.

Figures released last week by the National Science Foundation reveal that there is an increasing tendency for graduate scientists, engineers and technicians to enter service rather than manufacturing industries. These industries accounted for 60 per cent of the total growth of employment for graduates in the three categories between 1978 and 1980, even though only accounting for 40 per cent of the total employment.

Total science and engineering employment in private industry was virtually unchanged between 1970 and 1980 , but this trend may be reversed, however, if the current patterns of employment for this year's graduates is maintained.

David Dickson

\section{Soviet space programme \\ No shuttle yet?}

The high cost of space research is troubling Soviet planners as well as their counterparts in the space agencies of Europe and the United States. At a ceremony on 10 April commemorating the twentieth anniversary of Yurii Gagarin's first manned space flight, the president of the Soviet Academy of Sciences, Dr Anatoli P. Aleksandrov, spoke in a low key for such an occasion.

Aleksandrov's speech was little more than a justification of expenditure so far, and a defence of the proposition that the more that is spent on space, the greater the eventual benefit. This is not the first indication that Soviet space research may be running into financial difficulties. Earlier this year, the Soviet side had to make it clear to their French partners that if the two countries were to carry out a joint mission to Halley's comet, spending on their Venus mission of 1986 would have to be halved.

To demonstrate the priority being given to cost-effectiveness, Aleksandrov explained that three and a half years ago the cosmonauts aboard Salyut- 4 were working on behalf of only 40 scientific and industrial bodies, whereas in the latest mission, Vladimir Kovalenko and Viktor Savinykh on Salyut-6 were providing data for some $\mathbf{4 0 0}$ organizations.

Naturally Aleksandrov did not discuss any military aspects of the Soviet space programme, although he did add to the abuse of the US space shuttle as a military vehicle. The press in the Soviet Union suggest that the US shuttle is primarily for launching laser weapons into space.

Soviet intentions on reusable launching systems remain unclear, however. Aleksandrov did not discuss any such plans, but Soviet cosmonaut Vitalii Sevastyanov stated in the Slovak daily Pravda that the Soviets were considering the construction of a shuttle. He claimed, though, that the present conventional methods used in Soviet space launches were more convenient than a shuttle for their programme based on large orbital stations designed for "peaceful purposes" and "suitable for a longer stay in orbit of scores of specialists".

There is speculation in the West, however, that at least one experimental Soviet shuttle has been launched number 929 in the "Kosmos" unmanned satellite series.

Vera Rich 